\title{
ANALYSIS OF THE INFLUENCE OF MINING IMPACTS ON THE INTENSITY OF DAMAGE TO MASONRY BUILDING STRUCTURES
}

\begin{abstract}
The paper presents the results of the analysis of the extent of damage to building structures subjected to mining impacts in the form of tremors and continuous surface deformation. The two methods which were used included the multiple regression analysis and the Support Vector Machine - SVM, which belongs to the socalled Machine Learning. The study used the database of the design, technical condition and potential causes of damage to 199 non-renovated buildings, up to the age of 20 years, of a traditional brick construction, located in the mining area of Legnica-Głogów Copper District (LGOM). The conducted analysis allowed for the qualitative assessment of the influence of mining impacts on the extent of damage to the studied buildings.
\end{abstract}

Keywords: technical condition of buildings, buildings of masonry structure, mining impacts, Partial Least Squares Regression, multiple regression analysis, Support Vector Machine

\section{Introduction}

Periodic examinations and assessment of the technical condition are essential to ensure safety to building structures and to maintain a predetermined level of their utility value. In mining areas, periodic examinations of the technical condition of building structures is also performed in order to assess their resistance to mining impacts and to determine the extent of possible mining damage. During the inspection of the technical condition, the assessment of the extent and intensity of damage is particularly difficult, especially in the context of determining the causes of their origin.

In $[4,6]$, a proposal was presented for a universal classification of the intensity of damage to individual elements of buildings, both of masonry structure, made of prefabricated industrial systems (large-block, large-panel), as well as

\footnotetext{
${ }^{1}$ Karol Firek, AGH University of Science and Technology in Cracow, Department of Engineering Surveying and Civil Engineering; kfirek@agh.edu.pl
} 
portal frame structures. Basing on the information collected during the inspection, indices of the intensity of damage to the elements of buildings $w_{u i}$ were determined. Then, using the method of Partial Least Squares Regression - PLSR, the generalized damage intensity indices for different types of buildings $w_{u}$ were determined.

This paper presents the results of the analysis of the influence of mining impacts on the intensity of damage to masonry building structures, performed using the statistical method of multiple regression, which were verified using the method of Support Vector Machine - SVM, which belongs to the so-called $M a$ chine Learning. The study used the database of the design, technical condition and potential causes of damage to 199 non-renovated buildings up to the age of 20 years, located in the mining area of Legnica-Głogów Copper District (LGOM), which have been subjected to mining impacts in the form of continuous surface deformations and tremors.

\section{Research methodology}

\subsection{Multiple regression analysis}

The method of multiple regression allows to examine the combined influence of the factors determining the course of a specific process. During the study, a linear relationship between the input variables and the dependent variable is predetermined. Assuming that the approximated dependent variable can be written as a linear combination of the factors included in the description of the phenomenon, and having a set of the observation data, the parameters of the model are determined. These parameters are the slopes which occur with each variable. They demonstrate their qualitative and quantitative influence on the course of the approximated dependent variable. The basic procedure, which allows for the determination of these parameters is the method of least squares. This method requires that the distribution of residuals around the approximated surface was close to normal. Verification can be carried out based on the distribution analysis and normality plot of residuals. In addition, while determining model parameters by the method of least squares, it is required that the variance of random components for all observations was the same, and that there were no significant correlations between individual input variables (e.g. [13]). As a result, coefficients of multiple correlation $R$ and determination $R^{2}$, regression coefficients $(B)$ and standardized regression coefficients (BETA) are obtained. The values of BETA coefficient allow to compare relative contribution that each independent variable brings in the prediction of the dependent variable. 


\subsection{Analysis by support vector $S V M$}

In order to verify the results obtained, the method of Support Vector Machine $-S V M$ was used. This method is a tool which is used both to solve the problems of classification and regression (e.g. [10, 11, 12]). It also allows for an initial assessment of the influence of input variables on the course of the approximated value of the dependent variable.

The main advantage of the SVM method, in contrast to the conventional methods of artificial neural networks, is the uniqueness of the process of building a model and a high level of generalization of the acquired knowledge. The deterministic description of the $S V M$ approximator makes it retain the continuity and differentiability in the domain of input variables. The resulting advantage of the method is the possibility of carrying out a sensitivity analysis of the created model.

The main problem during the building stage of the $S V M$ model is to determine the optimal values of the parameters $C, \varepsilon$ and $\sigma$. The parameter $\sigma$ is the result of the adoption of the radial kernel function and for the built approximator it determines their width. On the other hand, the parameters $C$ and $\varepsilon$ are the regularization constant, and tolerance bandwidth, respectively. Selection of the parameters is performed by the gradientlessness optimization method Patternsearch, in the process of $n$-fold cross-validation [2].

\section{Description of the examined development}

\subsection{Technical characteristics of the study group of building structures}

The study used the information collected during the surveys carried out by the team of the Department of Engineering Surveying and Civil Engineering of AGH University of Science and Technology. On this basis, a database was established of 199 single-family residential buildings up to the age of 20 years, of a traditional brick construction, located in the mining area of Legnica-Głogów Copper District (LGOM). These are one or two-storey buildings.

In the buildings, preventive measures were taken for the mining area category II. A constant level of the foundation and concrete footings with additional longitudinal reinforcement were used. The basement walls were made as monolithic concrete or built of concrete blocks. The walls of the upper floors were built of cellular concrete blocks, slag concrete, ceramic blocks or ceramic bricks. The ceilings above the basements and the higher floors were made as monolithic reinforced concrete, of reinforced concrete prefabricated panels or beams and blocks. The roofings were wooden rafter framing or flat roofs. All the analyzed buildings had only been subjected to minor maintenance works and current repairs. 


\subsection{Indices of the technical condition of building structures}

\section{The degree of technical wear}

The measure of technical condition of building structures is the degree of their wear $s_{z}$. As part of the described research, the degree of technical wear was determined for individual buildings by the method of weighted average, taking into account individual construction and technological solutions (e.g. [17]). The studied buildings had the degree of wear $s_{z}$ up to $20 \%$.

\section{Indices $w_{u i}$ of the intensity of damage to the elements of a building structure}

In order to examine the contribution of damage to the technical wear of each building, the qualitative damage intensity index $w_{u i}$ was determined for the individual elements of the buildings (e.g. [4, 6]). Taking into account very different solutions used in the buildings, a total of 22 structural and non-structural elements were distinguished. The index $w_{u i}$ was defined in a 6-point scale, in which $w_{u i}=0$ means that the damage does not occur, $w_{u i}=1$ - slight damage, $w_{u i}$ $=2$ - moderate damage, $w_{u i}=3$ - intensive damage $w_{u i}=4$ (and 5) - very intensive damage.

When specifying detailed criteria for determining the damage intensity index for individual elements of the buildings, the author's own experience was used, as well as the findings of other authors, taking into account the specificity of the objects located in mining areas (e.g. [1, 3, 7, 8, 9, 15, 17]). Table 1 presents the exemplary detailed criteria for determining the damage intensity index $w_{u 3}$ for the load-bearing walls of the overground part of the building structure with respect to slight and moderate damage.

In the study group of 199 masonry buildings, the values of the damage intensity indices $w_{u i}$ were determined for their specific elements based on the data collected during the survey. The analysis of the values of the damage intensity indices $w_{u i}$ in the study group of buildings demonstrated that most of the objects were damaged slightly or moderately.

\section{Generalized building damage intensity index $w_{u}$}

Then, for each building, the generalized damage intensity index $w_{u}$ was determined as a linear combination of the intensity of damage to its individual components $w_{u i}$ (e.g. $\left.[19,20]\right)$. Partial Least Squares Regression method (PLSR) was used in the field of Data Mining (e.g. [18]). For the studied type of building structures, the following indices were specified, which described damage to the elements such as: basement load-bearing walls or foundation walls $\left(w_{u 2}\right)$, overground load-bearing walls $\left(w_{u 3}\right)$, ceilings over the basements $\left(w_{u 6}\right)$, ceilings of higher floors $\left(w_{u 7}\right)$, partition walls $\left(w_{u l 1}\right)$, internal plaster and wall coverings $\left(w_{u 12}\right)$, floors $\left(w_{u 13}\right)$, layers of cladding $\left(w_{u 17}\right)$, flashings and guttering $\left(w_{u 20}\right)$, as well as external elements such as landings, platforms, trims $\left(w_{u 22}\right)$. 
Table 1. Examples of detailed criteria for determining the damage intensity index $w_{u 3}$ for the loadbearing walls of the overground part of the building

Tabela 1. Przykład szczegółowych kryteriów ustalania wskaźnika intensywności uszkodzeń dla ścian nośnych nadziemia $w_{u 3}$

\begin{tabular}{|c|c|c|c|}
\hline $\begin{array}{l}\text { Damage } \\
\text { intensity } \\
\text { index } w_{u i}\end{array}$ & Definition & Description & $\begin{array}{l}\text { Detailed criteria for determining } \\
\text { the damage intensity index } w_{u 3} \\
\text { for the load-bearing walls } \\
\text { of the overground part of the building }\end{array}$ \\
\hline $\mathbf{0}$ & $\begin{array}{l}\text { No } \\
\text { damage }\end{array}$ & $\begin{array}{l}\text { Damage } \\
\text { does not occur, } \\
\text { or it is unnoticeable }\end{array}$ & There is no damage \\
\hline 1 & $\begin{array}{l}\text { Slight } \\
\text { damage }\end{array}$ & $\begin{array}{l}\text { Insignificant, minor } \\
\text { damage,occurring } \\
\text { in single cases }\end{array}$ & $\begin{array}{l}\text { Single scratches (tiny, hairline, microcracks), } \\
\text { with lengths reaching the whole floor height; } \\
\text { or } 1-2 \text { cracks up to } 1 \mathrm{~mm} \text { wide and } 1.5 \mathrm{~m} \text { long }\end{array}$ \\
\hline 2 & $\begin{array}{l}\text { Moderate } \\
\text { damage }\end{array}$ & $\begin{array}{l}\text { Moderate damage, } \\
\text { occurring locally, } \\
\text { in certain places }\end{array}$ & $\begin{array}{l}\text { local scratches (tiny, microcracks), or cracks } \\
\text { up to } 1 \mathrm{~mm} \text { wide, or } 1-2 \text { cracks up to } 3 \mathrm{~mm} \\
\text { wide; the lengths can reach the full floor } \\
\text { height; optionally, local minor scratches } \\
\text { and losses of mortar in the joints of the pre- } \\
\text { fabricated walls }\end{array}$ \\
\hline
\end{tabular}

As a result of the analysis using the PLSR method, it was demonstrated that the first component described by the formula (1) as a linear combination of the indices of the damage to structural and finishing elements of the building $w_{u i}$ can be the initial approximation of the generalized damage intensity index $w_{u}$. It allows to explain about $55 \%$ of the variability contained in the observed degree of technical wear $s_{z}$.

$$
\begin{gathered}
w_{u}=a_{2} \cdot w_{u 2}+a_{3} \cdot w_{u 3}+a_{6} \cdot w_{u 6}+a_{7} \cdot w_{u 7}+a_{11} \cdot w_{u 11}+a_{12} \cdot w_{u 12} \\
+a_{13} \cdot w_{u 13}+a_{17} w_{u 17}+a_{20} \cdot w_{u 20}+a_{22} \cdot w_{u 22}[\%]
\end{gathered}
$$

where: $w_{u i}$ - indices of the damage to structural and finishing elements of the building,

$a_{i}$ - slopes of the linear combination of the components, occurring at specific damage indices, determined by $P L S R$.

\subsection{Indices describing a risk posed to a development by mining exploitation}

\section{Risk index of continuous surface deformation}

Taking into account the specificity of continuous surface deformations in LGOM and the type of the studied development, the horizontal tensile strains $\varepsilon^{(+)}$ $[\mathrm{mm} / \mathrm{m}]$ were adopted as the basic measure of the risk of continuous surface deformations (e.g. [5]). 
Basing on the information from the local mines on the performed mining exploitation in these areas, each building was assigned a maximum value of the horizontal tensile deformation which occurred during the whole period of its existence. In all cases, the obtained values of $\varepsilon^{(+)}$are included in the mining area category I and II.

\section{Indices of the risk of mining tremors}

In order to assess the structural safety of a building, either the horizontal component of the acceleration of vibration $a_{H \max }$ or the velocity $V_{H \max }$ is adopted as a primary index for the risk assessment. The multiplicity of mining tremors affecting the building is not taken into account.

Such a procedure does not allow to assess the influence of mining tremors on the technical wear of the building. The analysis should take into account the fact of the repeatability of dynamic impacts, and thus the number and individual intensity of the influences of all seismic phenomena which significantly affect the structure over the whole period of its use.

In [16], the concept of the $a_{s g}$ index was introduced as a measure of the impact of mining tremors on the technical wear of building structures. It was defined as the geometric sum of the peak values of the horizontal component of the acceleration of ground vibrations occurring at the location of the building structure. Only those tremors were taken into account, which occurred during the period of the facility being used, and whose peak values at its location were greater than a predetermined threshold value of $a_{p}$, below which the impact of the tremors on the technical wear of the building was considered to be insignificant. The studies presented in [16] demonstrated that the optimal threshold value is $a_{p}=0.12 \mathrm{~m} / \mathrm{s}^{2}$.

The present study adopted the $a_{s g}$ index as a measure of dynamic impacts. This index was determined individually for each building, based on the analysis of all the tremors which occurred in the period from the erection of the building until the performed surveys.

\section{Results of the analysis}

\subsection{Results of the analysis of the intensity of damage to the studied development using multiple regression}

According to the adopted assumptions, the influence of mining impacts in the form of horizontal tensile strains $\varepsilon^{(+)}$and mining tremors represented by $a_{s g}$ on the intensity of damage to buildings $w_{u}$ were analyzed using multiple regres- 
sion. The estimation of the model parameters for individual groups of buildings was carried out using the computer program STATISTICA [14]. The results of the analysis are contained in Table 2.

Table 2. Results of analyzing the dependence of the damage intensity index $w_{u}$ on the mining tremors intensity indices $\varepsilon^{(+)}$and $a_{s g}$ using multiple regression method

Tabela 2. Wyniki badań zależności wskaźnika intensywności uszkodzeń $w_{u}$ od wskaźników oddziaływań górniczych $\varepsilon^{(+)}$i $a_{s g}$ przy użyciu metody regresji wielorakiej

\begin{tabular}{|c|c|c|c|c|c|}
\hline $\begin{array}{c}\text { Factor } \\
\text { (independent } \\
\text { variable) }\end{array}$ & $\begin{array}{c}\text { Standardized } \\
\text { regression } \\
\text { coefficient } \\
\boldsymbol{B E T A}\end{array}$ & $\begin{array}{c}\text { Coefficient } \\
\text { with inde- } \\
\text { pendent vari- } \\
\text { able } \\
\boldsymbol{B}\end{array}$ & $\begin{array}{c}\text { Significance } \\
\text { level } \\
\boldsymbol{p}\end{array}$ & $\begin{array}{c}\text { Correlation } \\
\text { coefficient } \\
\boldsymbol{R}\end{array}$ & $\begin{array}{c}\text { Coefficient of } \\
\text { determination } \\
\boldsymbol{R}^{\mathbf{2}}\end{array}$ \\
\cline { 1 - 4 }$\varepsilon^{(+)}$ & 0.201 & 5.99 & 0.005 & \multirow{2}{*}{0.229} & 0.052 \\
\hline$a_{s g}$ & 0.140 & 4.16 & 0.047 & \\
\hline
\end{tabular}

The presented results illustrate that the influence of the analyzed factors with respect to the studied development explain approximately $5 \%$ of the variability of the damage intensity index. The influence of mining impacts on the damage was demonstrated, as evidenced by the significance levels determined for the model parameters corresponding to the specific mining indices. The values of the standardized regression coefficients (BETA) demonstrated a relatively greater influence of the horizontal strain deformations $\varepsilon^{(+)}$(approx. 20\%) on the intensity of damage in the studied group of buildings, compared to the mining tremors represented by $a_{s g}$ (approx. 14\%).

The relationships between the analyzed independent variables and the actual values of the damage intensity index were illustrated in the graphical form in the three-dimensional scatterplot with the plane of fitting (Fig. 1). The nonlinearity which is visible on the graph was the reason for taking the decision to perform additional analyses using the $S V M$ method. 


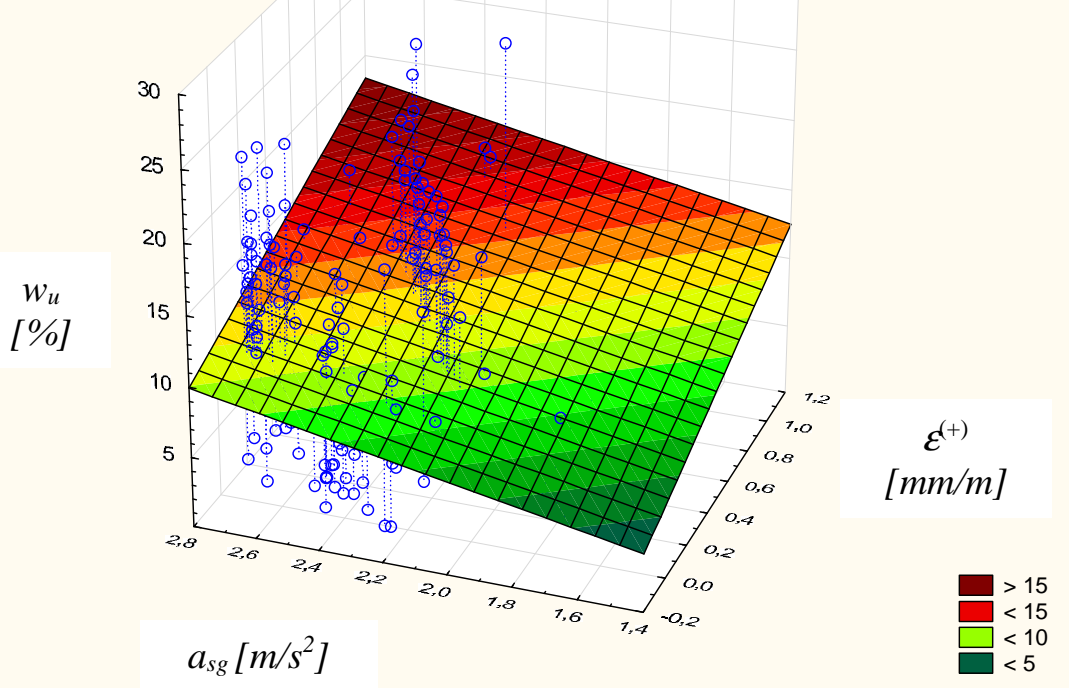

Fig. 1. The three-dimensional scatter diagram with the plane of fitting the damage intensity index for $\varepsilon^{(+)}$and $a_{s g}$

Rys. 1. Trójwymiarowym wykres rozrzutu z płaszczyzną dopasowania wskaźnika intensywności uszkodzeń dla $\varepsilon^{(+)}$i $a_{s g}$

\subsection{Results of the analysis of the intensity of damage to the studied development using the $S V M$ method}

In order to verify the results obtained by the method of multiple regression, the $S V M$ method was used for the analysis of the intensity of damage to the studied development. The comparison of the main model characteristics and the values of the Mean Squared Error - MSE for the training set and the test set were presented in Tables 3 and 4, respectively.

Table 3. Comparison of the values of the main characteristics of the model

Tabela 3. Zestawienie wartości podstawowych charakterystyk modelu

\begin{tabular}{|c|c|c|c|}
\hline \multicolumn{4}{|c|}{ Model parameters } \\
\hline $\begin{array}{c}\text { Regularization pa- } \\
\text { rameter } \\
C\end{array}$ & $\begin{array}{c}\text { Width of kernel } \\
\text { functions } \\
\boldsymbol{\sigma}\end{array}$ & $\begin{array}{c}\text { Width of tolerance } \\
\text { band } \\
\boldsymbol{\varepsilon}\end{array}$ & $\begin{array}{c}\text { Number of support } \\
\text { vectors }\end{array}$ \\
\hline 96 & 0.050 & 0.300 & 77 \\
\hline
\end{tabular}


Table 4. Comparison of the values of the MSE for the training and test sets

Tabela 4. Zestawienie wartości błędów MSE dla zbioru treningowego i testowego

\begin{tabular}{|c|c|}
\hline $\begin{array}{c}\text { Values of the } M S E \text { for the training set } \\
{[\%]}\end{array}$ & $\begin{array}{c}\text { Values of the } M S E \text { for the test set } \\
{[\%]}\end{array}$ \\
\hline 46.2 & 44.7 \\
\hline
\end{tabular}

The results contained in Table 3 illustrate that, as a result of a spontaneous extension of the $S V M$ model, the size of its structure (the number of support vector - 77) was reduced by about 50\% compared to the size of the training set (142). This is a result of the regularization, which occurs in this type of approach.

On the other hand, the approximate values of the MSE summarized in Table 4 , calculated for the training and test sets, prove a good model generalization.

The resulting value of the correlation coefficient between the actual and the approximated values of the damage index at the level of 0.302 allows for the initial assessment of the cumulative influence of mining impacts on the extent of the damage to the surveyed buildings. This result is similar to the correlation coefficient calculated by the linear method of multiple regression.

\section{Summary and conclusions}

The paper presents the results of the analysis of the influence of mining impacts on the intensity of damage to masonry building structures located in the mining area by using the method of multiple regression and Support Vector Machine.

The study used the database of the design, technical condition and potential causes of damage to 199 non-renovated masonry buildings, up to the age of 20 years, located in the mining area of Legnica-Głogów Copper District, which during their use were subjected to mining impacts in the form of continuous surface deformations and rock mass tremors.

The analyses carried out by the method of multiple regression confirm the significant influence of mining impacts, both in the form of continuous surface deformations and mining tremors on the intensity of damage to the studied buildings. These results were confirmed by the SVM method.

It was found that the influence of the analyzed factors explain approximately $5 \%$ of the variability of the damage intensity index for the surveyed buildings.

Interpreting the described test results it should be remembered that the analyzed buildings are generally in good technical condition, and their average wear rate is $10 \%$.

The presented results are a confirmation of the effects of the research studies carried out for the traditional development of the mining areas using classical statistical methods (e.g. [17]), and are evidence of the suitability of the methods 
used to analyze the scope and causes of damage to the buildings constructed in different technologies, subject to mining impacts.

\section{Literature}

[1] An advanced approach to earthquake risk scenarios with applications to different european towns. RISK-UE Project EVK4-CT-2000-00014. Fifth Framework Programme, 2001-2004.

[2] Chang C-C., Lin C-J.: LIBSVM: a Library for Support Vector Machine. Software available at: http://www.csie.nyu.edu.tw/ cjlin/libsvm. 2008.

[3] European Macroseismic Scale 1998. European Seismological Commission, Editor G. Grünthal, Luxembourg 1998.

[4] Firek K., Rusek J., Wodyński A.: Wybrane metody eksploracji danych i uczenia maszynowego w analizie stanu uszkodzeń i zużycia technicznego zabudowy terenów górniczych. Przegląd Górniczy Nr 1/2016, s. 50-55, Katowice 2016.

[5] Firek K., Wodyński A.: Assessment of surface deformation impacts on technical wear of masonry buildings located in the Legnica-Głogów Copper District. Schriftenreihe des Institutes für Markscheidewesen und Geodäsie an der Technischen Universität Bergakademie Freiberg, 8 Geokinematischer Tag, Freiberg 2007.

[6] Firek K.: Proposal for classification of prefabricated panel building damage intensity rate in mining areas (Propozycja klasyfikacji intensywności uszkodzeń budynków wielkopłytowych na terenach górniczych). Archives of Mining Sciences. Wydawnictwo Instytutu Mechaniki Górotworu PAN, Vol. 54, Iss. 3, Kraków 2009.

[7] Hajdasz H.: Sposoby ustalania zużycia technicznego budynków i budowli. Katowice 1992.

[8] Kawulok M.: Szkody górnicze. ITB. Warszawa 2015.

[9] Lewicki B.: Budynki wielkopłytowe - wymagania podstawowe. Zeszyt 1. Metodyka oceny stanu technicznego konstrukcji budynków wielkopłytowych. Instytut Techniki Budowlanej. Seria: Instrukcje, Wytyczne, Poradniki nr 371/2002, Warszawa 2002.

[10] Łęski J.: Systemy neuronowo-rozmyte. WNT. Warszawa 2008.

[11] Rusek J.: Creating a model of technical wear of building in mining area, with utilization of regressive SVM approach. Archives of Mining Sciences. Wydawnictwo Instytutu Mechaniki Górotworu PAN, Vol. 54, Iss. 3, Kraków 2009.

[12] Schölkopf B., Smola A.J.: Learning with Kernels. Cambridge, MIT Press. Massachusetts 2002.

[13] Stanisz A.: Przystępny kurs statystyki z zastosowaniem STATISTICA PL na przykładach z medycyny. StatSoft Polska Sp. z o.o., Kraków 2007.

[14] Statistica 12. StatSoft, Inc. 2016.

[15] Tatara T.: Działania drgań powierzchniowych wywołanych wstrząsami górniczymi na niską tradycyjną zabudowę mieszkalną. Zeszyty Naukowe Politechniki Krakowskiej, seria: Inżynieria Lądowa, nr 74, 2002. 
[16] Wodyński A., Lasocki S.: Badanie wpływu wstrząsów górniczych na zużycie techniczne budynków murowanych. Przegląd Górniczy nr 12, Katowice 2003.

[17] Wodyński A.: Zużycie techniczne budynków na terenach górniczych. Uczelniane Wydawnictwa Naukowo Dydaktyczne AGH, Kraków 2007.

[18] Wold S., Sjostrom M., Eriksson L.: PLS-regression: a basic tool of chemometrics. Chemometrics and Laboratory Systems 58, 2001, s. 109-103. [Unpublished].

[19] Firek K.: Ocena intensywności uszkodzeń budynków o konstrukcji murowanej usytuowanych na terenie górniczym. Artykuł przyjęty do druku w: Przegląd Górniczy Nr 1/2017, Katowice 2017.

[20] Firek K., Rusek J.: Metoda cząstkowych najmniejszych kwadratów w analizie intensywności uszkodzeń budynków wielkoblokowych. Artykuł przyjęty do druku w: Archives of Mining Sciences. Wydawnictwo Instytutu Mechaniki Górotworu PAN, Kraków 2017.

\section{ANALIZA WPEYWU ODDZIAEYWAŃ GÓRNICZYCH NA INTENSYWNOŚĆ USZKODZEŃ BUDYNKÓW MUROWANYCH}

\section{Streszczenie}

W referacie przedstawiono wyniki analizy zakresu uszkodzeń budynków poddanych oddziaływaniom górniczym w postaci wstrząsów oraz ciągłych deformacji terenu. Posłużono się statystyczną metodą regresji wielorakiej oraz metodą wektorów podpierających (Support Vector Machine - SVM) zaliczaną do tzw. uczenia maszynowego (Machine Learning). W badaniach wykorzystano bazę danych o konstrukcji, stanie technicznym i potencjalnych przyczynach uszkodzeń 199 nieremontowanych budynków w wieku do 20 lat, o tradycyjnej konstrukcji murowanej, usytuowanych na terenie górniczym Legnicko-Głogowskiego Okręgu Miedziowego (LGOM). Przeprowadzona analiza pozwoliła na jakościową ocenę wpływu oddziaływań górniczych na zakres uszkodzeń badanych budynków.

Słowa kluczowe: stan techniczny budynków, budynki o konstrukcji murowanej, wpływy górnicze, metoda cząstkowych najmniejszych kwadratów $(P L S R)$, analiza regresji wielorakiej, metoda wektorów podpierających $(S V M)$

Przestano do redakcji: 05.12.2016 r.

Przyjęto do druku: 31.03.2017 r. 